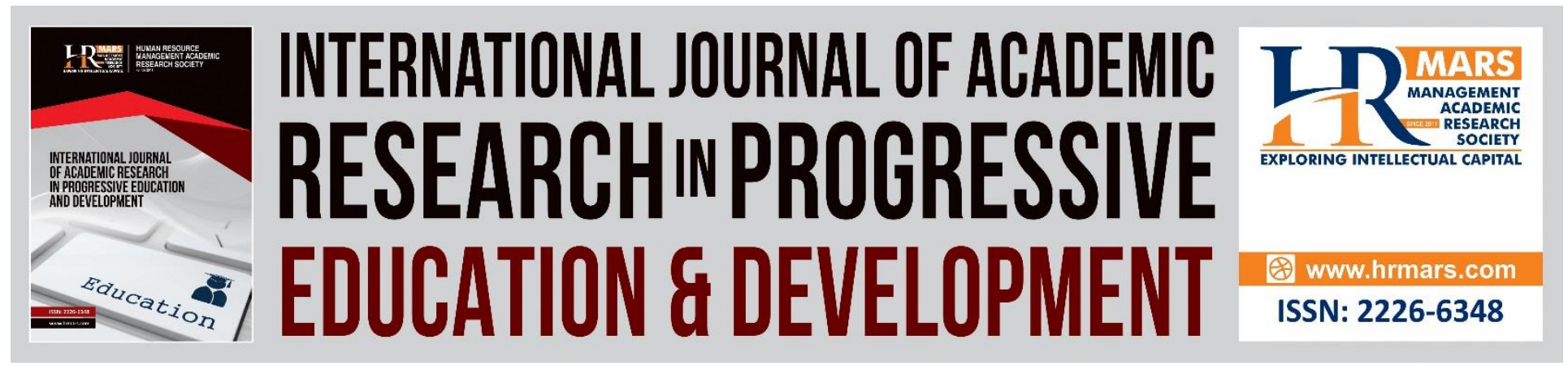

\title{
Pleasure Reading Enthusiasm on English Reading Materials Among Primary School Students
}

Ramunah Mohram, Zamri Mahamod, Wan Muna Ruzanna Wan Mohamad

To Link this Article: http://dx.doi.org/10.6007/IJARPED/v10-i1/8989

DOI:10.6007/IJARPED/v10-i1/8989

Received: 31 December 2020, Revised: 28 January 2021, Accepted: 17 February 2021

Published Online: 28 February 2021

In-Text Citation: (Mohram et al., 2021)

To Cite this Article: Mohram, R., Mahamod, Z., \& Mohamad, W. M. R. W. (2021). Pleasure Reading Enthusiasm on English Reading Materials Among Primary School Students. International Journal of Academic Research in Progressive Education and Development, 10(1), 321-330.

Copyright: (C) 2021 The Author(s)

Published by Human Resource Management Academic Research Society (www.hrmars.com)

This article is published under the Creative Commons Attribution (CC BY 4.0) license. Anyone may reproduce, distribute, translate and create derivative works of this article (for both commercial and non-commercial purposes), subject to full attribution to the original publication and authors. The full terms of this license may be seen

at: http://creativecommons.org/licences/by/4.0/legalcode

Vol. 10(1) 2021, Pg. 321 - 330

http://hrmars.com/index.php/pages/detail/IJARPED

JOURNAL HOMEPAGE

Full Terms \& Conditions of access and use can be found at http://hrmars.com/index.php/pages/detail/publication-ethics 




\title{
Pleasure Reading Enthusiasm on English Reading Materials Among Primary School Students
}

\author{
Ramunah Mohram, Zamri Mahamod, Wan Muna Ruzanna Wan \\ Mohamad \\ Faculty of Education, Universiti Kebangsaan Malaysia, National University of Malaysia, Pusat \\ Kembangan Pendidikan, Aras 2, Bangunan Wawasan, 43600 UKM Bangi \\ Selangor
}

\begin{abstract}
The purpose of this article is to reveal and understand the factors that influence the passion for reading English reading materials among the primary school students in general. From the author's point of view, the passion for reading English reading materials among primary school will directly help them to improve on the command of the language besides opening the minds to another height of comprehending and exploring the knowledge written internationally. This article is just a surface discussion on matters pertaining to reading and the author's personal perception and opinion on reading English reading materials among primary school students. It does not reflect the actual reading situation of any particular institution or individuals. The most significant consideration here would be the ability to inculcate the reading interests in the reading of the English reading materials as one of the definite way to improve pupils' comprehension and to enhance their command of the language. Hence will ultimately, helped to improve the students' learning process in the long run.
\end{abstract}

Keywords: Reading, Enthusism, Materials, Primary, School.

\section{Introduction}

Reading entails simple learning skill but yet significant in the implementation of the teaching and learning process. Reading serves as the main complements to the learning execution in many ways. According to Krashen (2003), reading for pleasure has been found to be improving reading comprehension, writing style, enriching vocabulary, spelling and grammatical development. Without possessing this reading skill, students' learning can be very slow, depleting and less effective. Being the most useful of the four language skills which is speaking, reading, writing and listening, reading was taught even on the very first day when the students endure their formal schooling years. In principle, reading is the most prominent skill which is immediately introduced to students in school where education is concerned. Dulice (1990), Reading is possibly the most useful of the four language skills which students in school have to master in their learning of a 
second language or foreign language in school as it is a required skill for higher studies or for acquiring further knowledge and information.

\section{Reading Among Students}

Reading is a very active process of stimulating students' minds and intellectual development. It also stimulates their cognitive process that would then replenish the students' knowledge and reading abilities in the long run. Rubin (2013) stressed that reading is a very complex and dynamic process that combines a reader's prior knowledge, social life, experience and emotions with the minds of the readers in their effort to interprets the reading materials. Lack of reading will impede the achievements of students in their academic learning development. On the contrary, active readers will benefit from such positive attitudes. Students with less enthusiasm to read will deprive themselves from the advantage of acquiring and sustaining knowledge thus being knowledgeable.

Reading English reading materials is one method of learning that is not arduous to master as students' reading abilities and reading in the English language need to be developed as early as the years in the schooling sphere. However, what is more prominent are the students' abilities to sustain the healthy reading habits which is beneficial in the course of achieving their learning objectives. To inculcate a strong reading foundation in reading English reading materials among students takes serious effort that requires careful attention and exertion. Student's narrow perception and interpretation on reading deprived them from understanding what reading is and they could not reason out their purpose for reading. Wallace (2016) stated that, one of the difficulties with regard to reading is that, many of the students do not know whether the ability to read is supposed to involve understanding what is read. Although students in general understand reading can guarantee them the abundance of knowledge in which the world has to offer.

Likewise, although reading proves to be the essence in language learning, most of the students seldom take up reading as serious habits in the long run. Most of the students only recognize reading as a skill to assist them in their academic purposes per say. Not many students regard reading as an advantage to ensure further progress in life. Sinau (2014), agreed that the students who resorted to serious reading are those who are pressured to struggle hard so as to excel in the examination. To sustain reading as a habit among students will always pose problems to teachers and to promote students to read English reading materials will need proper planning and guidance without jeopardizing student's interests to learn in their local context. Students often overlook the fact that reading plays a very significant role in unleashing their minds and broadening their knowledge to explore the contemporary information derived from the books, journals, magazines and even to the extent of going beyond the global cyber world. Furthermore, being reluctant to read and refraining from reading English reading materials will limit students' exposure, impedes them from composing good supporting facts when answering and addressing questions in tests and denies them of appropriate usage of the language in terms of grammar and vocabulary. 
Encouraging reading at an early stage in primary school level will always be the aspirations of every educational policy of almost every nations and not exempting our Malaysian Ministry of Education. Contemporary reading skills and learning emphasizes students to read even before they entered the formal learning process in Primary One. This was clearly stated in the Malaysian Primary School for the English curriculum integrating reading with listening, speaking and even writing skill since the nation's independence till today. Parallel to such effort in enhancing reading skill at the early stage was the introduction of the Pre School, a two year programme of pre schooling whereby students should be taught to read and mastered reading as early as they entered Pre School. Besides that, another project known as Nilai IImu Amalan Membaca (NILAM) or Reading and Writing Intensive course was introduced even before 2003 complement such effort.

It is vital to promote and sustain student's interest in reading to reduce the illiteracy rate among students in the country. Literacy development will always be prioritized in the education system in a developing nation like Malaysia in preparation for the nation's aspiration beyond the year 2030. In addition to that, reading must be able to fabricate the fresh young minds by which the nation's human potentials can be extracted and executed to the maximum. Long \& Abdullah (1984) emphasized that in this globalize world, the survival, advancement and development of the country requires the command, practicality and positive culture towards reading especially among the younger generation in our effort to develop and transform our public into a knowledgeable and informative citizen. This is always the priority and agenda for the Minisry of Education in improving the quality of education of the nation.

Dwelling reading and stimulating reading habits will always be an arduous effort which is certainly not easy to inculcate and embedded in every student. All these pose challenges to teachers and educators in assuring the younger generations to take up reading seriously. Though admittedly there were some hard core less enthusiastic students who are not concern to take the effort of reading seriously. This behaviour will create complications in their learning process when the students are in the upper primary level from the age of 10 to 12 years. Professionals in the teaching of second language agreed that English As Second Language Learners (ESL) who read extensively, will greatly improve their command of English. (Krashen, 2004; Krashen and Terrel, 2013)

Taking into consideration the reading problems among students, the author believes that by developing the reading interests and enthusiasm towards reading among the students by reading English reading materials should be made mandatory even at preschool level. This effort utilized the reading aloud, guided reading and extensive reading strategized to rectify and help students to sustain the reading habits among the students. In the initial stage, the author anticipates that the factors and reasons why students are lacking of interest in reading the English reading materials as this forms a very important aspect and foundation for learning English. Furthermore, with reference to the adoption and adaptation of certain areas in the motivational reading strategies (Megat Rohani, 2011) the author hopes to break the negative students' perceptions 
towards reading in the English Language and sustains their reading interest to the maximum when reading English reading materials.

Our nation's vision in becoming a developed high income country posed us to various challenges ahead. One of the challenge is to acquire and utilized as much knowledge as possible at our advantage so as to be on par with other developed nations. Regardless of the urban or rural school setting and in an effort to acquire knowledge, it is vital to enhance the students' motivation to read even as early as the preschool level. Without a proper attitude and mentality towards reading and reading English reading materials plus no genuine interests, reading among students will slow down the energy and deterred the nation's aspirations in advancing towards a developed country by the year 2030 parallel to the fast changing world in the midst of globalization.

It is very important to comprehend the students' attitude and enthusiasm for reading especially at the primary school level because they form the substance and cream of the nation's potential human capital that need to be dwelled and utilized. It is important to provide a better understanding of the students' distinct characteristic that will give us the idea on the significance of the students reading, the efforts taken to remedy this situation and also the ability to sustain the students' reading habits.

Furthermore, with the emphasis given on English language, reading cannot be avoided to help the students improve on the target language. At the same time, to develop and inculcate the positive habitual long life reading among student by persuasion per say may only give them a minimum impact in the short run. Students' active involvement and participation in reading will provide the teachers the extra help and the correct the student attitude towards reading. Hence the importance to promote the reading habits using the appropriate strategies at the suitable time will be an advantage.

Reading English language reading materials proved to be very distinguishing towards ensuring the students' escalating interests and mastery of the language. This effort should be a continuous growing process in every individual but what is more indispensable were to ensure the uninterrupted and sustainable endless effort exerted to materialize reading objectives. The objective of this article aimed to identify the reading English reading material and other facet in motivating students to read in the English language where majority of the students were the nonnative speakers of the English language. The motivational features emphasized were both from the motivational aspects and the practical aspects with the hope to develop enthusiasm for reading English reading materials. Moreover, the objectivity of this motivational practice was capable to maneuver the correct reading strategies and successfully stimulate reading for the benefit of the students in the long run.

The article intended to exposed the reading development among individuals reading English reading material among the students in the primary school and more importantly sustained the reading habits as a positive characteristic within. Besides, the article foresees reading English reading materials among primary school students as an alternative endeavor to inculcate the 
promising reading habits among student's and therefore unveiled their potentials as good learners of English. However, the article distinguished that motivating students was not an easy task and this painstaking effort consumed time, perseverance and the appropriate reading approaches.

\section{Conceptual Framework}

The Conceptual framework of this research exposed the attempts of the researcher to comprehend the existing reading English reading materials problems among the students. The very basic way of comprehending the reading scenario was through the usage of the questionnaire. This provides the foundation of reliable data that helps the researcher in trying to empathize and discern the factors that influenced the students' passion for reading and their preferences. Hence, this will greatly help in the authenticity and verification of the data acquired to help reveal on the underlying reading problems among the students in the form of facts and figures.

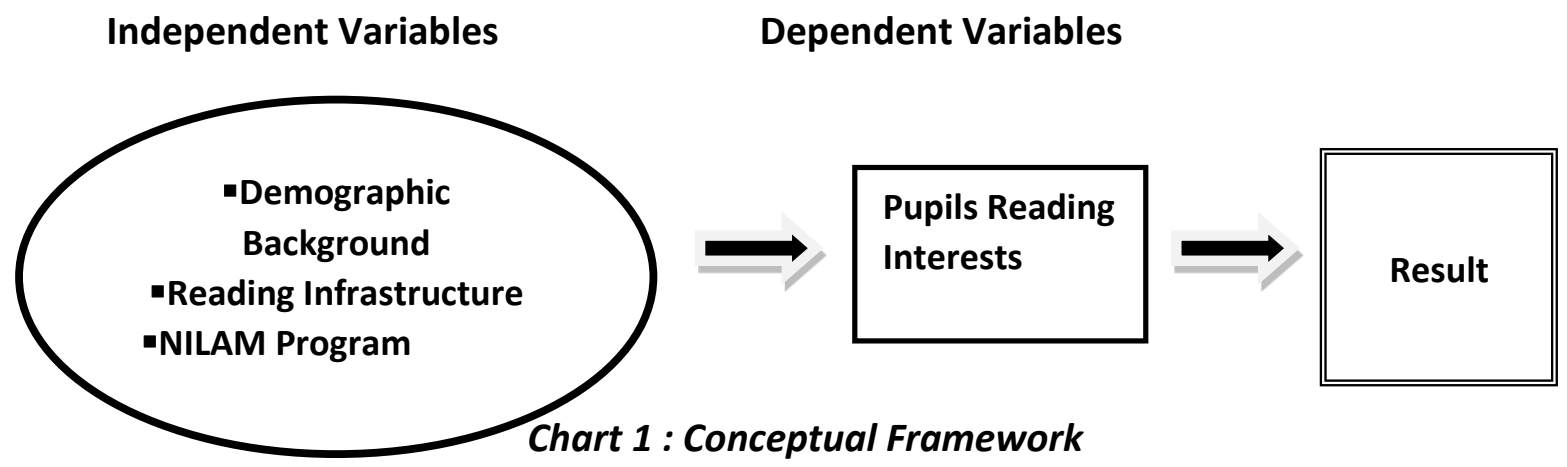

\section{Methodology}

A glimpse into the reason for this study is to understand the current reading habits among students and their preferences for reading the reading of English reading materials that need to be revitalized. To discover out further the subject, instrument used would be structured questionnaires, interviews and personal observations. This form the foundation for comprehending and identifying the factors that influence the reading habits and preferences. Based on such factors, provide us the required information and data that enable the researcher to formulate the practical strategies in the effort to overcome the problem.

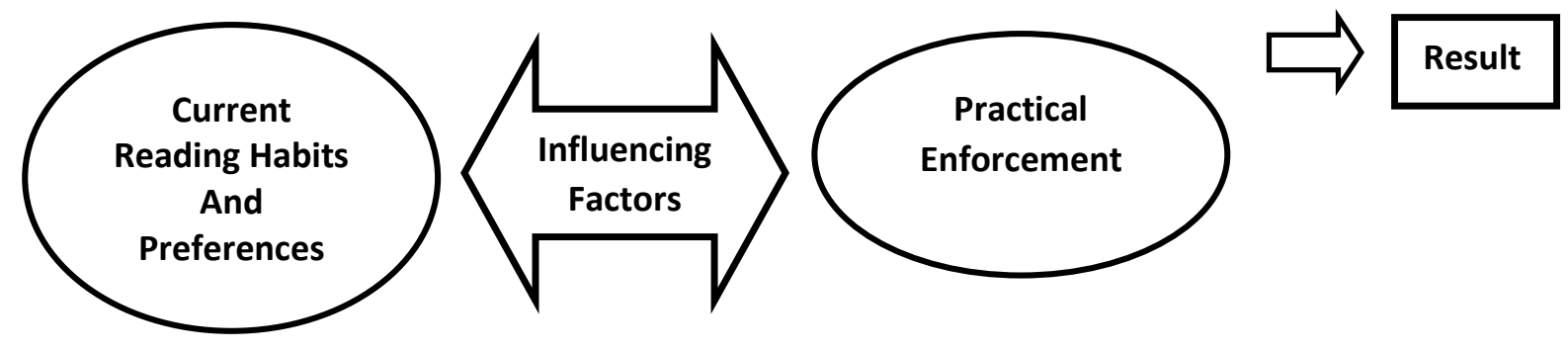

Chart 2: Research Design and Strategies 
There were 32 questions consisting of both a closed type and opened typed questions were used explore and reveal the students' interests, preferences and enthusiasm in reading. The questions were meant to provide diversified information whereby the respondents were given the liberty to express their views or suggestions in the questionnaire. Questions were designed and structured according to the kind of information needed for the study. Before the questionnaire was employed, a pilot test was conducted to gauge the reliability and validity of the questionnaire.

To enable the respondents to understand the content of the questionnaire better, the questionnaire adopted a dual language of both the English and Malay Language. The researcher believed that this would give clarifications to the respondent and minimize their doubt on the requirements of the items in the questionnaire. Furthermore, on-going observations were done over a period of one month to check on the students' attendance at the library or based on the Nilam or Sapphire reading program. This would enable the researcher to get an unambiguous picture on the students' passion for reading.

\section{Findings}

Within every individual there should be some form of drive that enable them to have both the intrinsic and extrinsic motivation to read. Interests is the key factor for this to happen but it will not crop up naturally in every individual thus requires time, influence, environment and above all the correct attitude. Interests can be developed, groomed and nurtured over a period of time depending on the interests' level of the students plus the enthusiasm to read. Not many students have this remarkable interests and many still struggling to read just to compensate the need of their learning process in school.

Family's accountability plays a very significant role in the student's learning environment. Every family will have their own personal varied and diversified academic background. Each will have different approaches and perspectives in learning. Despite being different in their academic background, the one giving the most priorities to learning will read more regardless of their economic advantage. Mentality, perceptions and competitive environment triggers the family to look forward to reading as the dominant activity in their children learning process.

Most students will access to the different form of reading materials. Good library infrastructures and the accessibility to good internet connection will provide the extra advantage for the students to read. It leaves them to the choice of reading good quality reading materials for their academic purposes or simply reading aimlessly. Students now days prefer online reading materials which is very easy to access as compared to the books available in the library or sold online or in the open market. As such reading can always take place anywhere at any time but much depends on the individual students' attitude, enthusiasm and perceptions on their aim and objectives in reading.

Assignments and homework given by teachers for students daily were not synchronized and structured to the time and capacity of every individual student. Some were merely given based on the whims and fancies of the teachers but not much in helping and promoting students' interests to read. Reading just to cater for the academic purposes only have minor impact on the students reading interests. Assignment and homework are meant to keep the students engaged 
to their learning syllabus after school but not to develop, instill and inculcate good and promising reading habits among students.

\section{Conclusion}

Reading English language materials proved to be very distinguishing towards ensuring the students' escalating interests and mastery of the English language. Although this effort should be a continuous growing process in every individual but what was more indispensable were to ensure the uninterrupted and sustainable endless effort exerted to materialize reading English Reading Material's objectives. The outcomes and implications of the study in correlation to the factors that influenced the students' interests and passion towards the reading of the English reading materials can be identified and referred to for further references. Furthermore, future studies are also discretionarily recommended to look into the congruence area in a more intensive but specific perspective area with the effort to edifice the research towards a more appealing and comprehensive subject area.

\section{Acknowledgement}

Bismillahhirahmannirahim.

Thanks to almighty Allah subhanahuwaataala (s.w.t) for the blessing in making this research article a success.

My utmost gratitude and appreciation are extended specially to my dedicated and understanding supervisor, Professor Doctor Zamri bin Mahamod and Dr. Wan Muna Ruzanna Wan Mohamad for their guidance in helping me to complete this research. A special thanks to all the lecturers that had taught and help me throughout this program, without them it would be almost impossible for me to accomplish it till this point.

Thanks to University Kebangsaan Malaysia for the Philisophy of Education in Bahasa Melayu program offered. Throughout these two years, I learned a lot to equip myself for my future undertakings though the rest will depend on myself to dig with persistence, passion and perseverance. This golden opportunity you have given me made my virtuous dream comes true and to those who had assisted me either directly or indirectly, especially to my boss Mr Kalana bin Ali Hassan for allowing me to write this article and not forgetting those whom I could not enunciate, I am deeply indebted.

Dedication and thankful also to my husband, Kamaludin Bin $\mathrm{Hj}$. Gabut, daughters and son for their tranquility, sacrifices either in the form of moral and material, understanding my situations during the hard time within the years of the program. They are my truly greatest inspirations.

\section{References}

Abu, M. S., \& Tasir, Z. (2001). Pengenalan Kepada Analisis Data Berkomputer SPSS Vr. 10., Kuala Lumpur: Venton Publishing.

Alvermann, D. (2000). Content Reading and Literacy. USA: Pearson Education Boston. 
INTERNATIONAL JOURNAL OF ACADEMIC RESEARCH IN PROGRESSIVE EDUCATION AND

DEVELOPMENT

Vol. 10, No. 1, 2021, E-ISSN: 2226-6348 @ 2021 HRMARS

Azam, M. N. (1994). Projek gerakan membaca. Persidangan Gerakan Membaca. Kuala Lumpur: Dewan Bahasa dan Pustaka.

Brown, H. D. (1993). Principles of Language Learning and Teaching. (3rd ed.). USA: Prentice Hall Regents.

Chiah, S. C. (1993). Tabiat membaca dikalangan murid-murid tahun enam Sekolah

Child, D. (1997). Physcologhy and The Teacher. (6th ed.). London: Holt Rinehout \& Winston Wellington House.

Chitravelu, N., Sithamparam, S., \& The, S. C. (1995). ELT Methodology: Principles and Practice. Shah Alam: Penerbit Fajar Bakti.

Drecher, M. J. (2000). Engaging Young Readers. New York: Guilford Press.

Dulice, A. (1972). Planning and Teaching: Practical Suggestions for English in The Classroom. Petaling Jaya, Selangor: Fajar Bakti

Frank, S. (1998). Profile membaca rakyat Malaysia. Kuala Lumpur: Perpustakaan Rakyat Malaysia. Graves, M. F. (2001). Teaching Reading in the 21st Century. USA: Pearson Education.

Kaur, S., \& Thiyagarajah, R. (1999). The English Reading Habits of the English Language and Literature Studies undergraduates in University Sains of Malaysia. Paper presented at the "Sixth International Literacy and Education Research Network conference in Learning" Bay View Beach Resort; Penang Malaysia: USM.

Kibat, K. K. (1978). Kajian Tabiat dan Tabiat Membaca di Negeri Trengganu. Paper presented at national seminar on the promotion of reading habits in Malaysia. (1994, June).

Kibat, K. K. (1978). Reading Habits and Interests of Rural Malays: A Methodological Study of the Printed Media in Rural Areas in Selangor. Selangor: University of Pittsburgh.

Krashen, S. (1993) The Power of Reading. Eaglewood: Libraries Unlimited.

Long, A. (1984). Malaysian Reading Habits. Education Ministry. Kuala Lumpur: Dewan Bahasa Dan Pustaka

Long, A., Othman, G., Abdullah, M. N., \& Yoong, S. (1984). A survey on reading habits and interests of Malaysians. Kuala Lumpur: Dewan Bahasa Dan Pustaka

Long, A., Othman, G., Abdullah, M. N., Abidin, Z., \& Yoong, S. (1984). A survey on reading habits and interests of Malaysians. Kuala Lumpur: Dewan Bahasa Dan Pustaka

Master English or nation will lose out. (2004). New Sunday Times: Malaysia pp.1

Mokhtari, K., \& Sheorey, R. (1994). Reading habits of University ESL students at different level of English proficiency and education. Journal of research in reading, 17, 46-61.

Muhamad, M. T. (1994). Pembacaan masyarakat luar Bandar Semenanjung Malaysia. Paper presented on the national seminar on the promotion of reading habits in Malaysia. Selangor Darul Ehsan: University Malaya.

Nair, M A. (2000). Teaching of English As A Foreign Language: Methods, Approaches And Techniques. Kuala Lumpur: Utusan Publication.

Nunan, D. (1989). Understanding Language Classroom. A guide for initiated action. New York: Prentice Hall.

Rahim, P. R. M. A. (2011). Using Motivational Techniques to Teach Reading. Universiti Teknologi Mara: Perak.

Sivley, D. (2002). Reading Inside Out. New York USA: Pearson Education Inc.

Spink, J. (1989). Children as Readers. London: Clive Bingley. 
INTERNATIONAL JOURNAL OF ACADEMIC RESEARCH IN PROGRESSIVE EDUCATION AND DEVELOPMENT

Vol. 10, No. 1, 2021, E-ISSN: 2226-6348 @ 2021 HRMARS

Stephen, K. D., \& Terrel, T. D. (2013). The National Approach: Language Acquisition in The Classroom. USA; Sixth Edition: Perqamon Press.

Steven, F. (2001). How Children Learn to Read. Cedric Cullingford, London: Pentonville.

Students told to adopt philosophy of continious learning. (2004, August 15). The Borneo Post. p. A1.

Tai, S. (2004). Reading Habits Among Primary Six Pupils: A Study In Sekolah Kebangsaan Sampun AS.49 Asajaya, Samarahan, Sarawak : S.K Sampun, Samarahan Sarawak. Sarawak: UiTM Campus Samarahan

Wee, R. (2003). Reading Interests amongst 543 First Semester Diploma Students, Sarawak. Sarawak: UiTM Campus Samarahan.

William, W. E. (2016). Reading in The Language Classroom. (5th ed.). UK: Macmillan.

Williams, W. M. (1996). The Reluctant Reader. USA Werner Books: New York. 